\title{
Case Study: Productive Performance and Prediction of Operating Income of Small-Scale Contract Farming of Swine in Lampang, Thailand
}

\author{
Suntorn Wittayakun ${ }^{1}$, Worawut Chainetr ${ }^{1}$, Nirundorn Kongngoen ${ }^{1}$, Weera Innaree ${ }^{1}$, Piyamas Tancharoenrat ${ }^{1}$ and \\ Ir. Marjuki ${ }^{2}$ \\ 1. Faculty of Science and Agricultural Technology, Rajamangala University of Technology Lanna, Lampang Campus, 200 Mu 17 \\ Pichai District, Muang, Lampang 52000, Thailand
}

2. Faculty of Animal Science, Brawijaya University, Jl. Veteran Malang, Ketawanggede, Kec. Lowokwaru, Kota Malang, Jawa Timur 65145, Indonesia

\begin{abstract}
The objective of this study was to examine productive performance and predict factors affecting operating income of small-scale contract farming of swine (SCFS) in Lampang, Thailand. Ten SCFSs were selected by purposive sampling as primary data sources for two consecutive fattening cycles during the year 2015-2017. Data indicated that the SCFS was feeder pig finishing system which herd size (HS) averaged 502 head/farm. The animals consumed approximate $1.59 \mathrm{~kg}$ of feed/head/d. The average daily gain (ADG) was $675.22 \mathrm{~g} / \mathrm{d}$ and feed conversion ratio (FCR) was 2.42 . The mean of fattening time (FT) averaged $158 \mathrm{~d} / \mathrm{cycle}$. The culling rate $(\mathrm{CR})$ and mortality rate (MR) were $0.17 \%$ and $2.50 \%$, respectively. The predicted operating income (POI) was estimated by multiple linear regressions. The equation was: $\mathrm{POI}=2,700.912+0.027 \mathrm{HS}-7.119 \mathrm{CR}-18.225 \mathrm{MR}+16.885 \mathrm{ABW}+806.466 \mathrm{FI}-$ 4.142ADG - 420.281FCR - 9.719FT (ABW = average body weight; FI = feed intake) with $r=0.899, r^{2}=0.808, p$-value $=0.009$. According to stepwise procedure, the potential equation was: $\mathrm{POI}=323.664 \mathrm{FI}-9.769 \mathrm{MR}-22.635$ with $r=0.837, r^{2}=0.701$, $p$-value $=0.000$. This predicted equation would benefit as a monitoring index for SCFS to manage their expected operating income and proper farm management to be further profitable and sustainable.
\end{abstract}

Key words: Contract farming, swine, operating income.

\section{Introduction}

Swine production is one of the important livestock businesses to generate income and prosperity to Thai farmers. Based on the Department of Livestock and Development, more than 100,000 farms have been operated nationwide [1]. In recent years, swine production in Thailand has been dramatically shifted from the backyard to commercialized or industrialized systems in response to the improvement of related production technology and marketing networks $[2,3]$. Swine contract farming is an attractive business model

Corresponding author: Suntorn Wittayakun, associate professor, research fields: animal nutrition and animal production. in the swine production industry by having a private company as a partnership to support farm input, animal health service, management monitoring, marketing and operating income based on farm output [4-6]. In Thailand, small-scale contract farming of swine (SCFS) is relatively sustainable and quite mature, characterized by raising boar and sow or finishing pigs or piglet or combination of different phases of age with an approximate number of pigs between 50-500 head or the livestock weight between 6-60 units [2]. In Thailand, SCFS accounts only 10\% of swine farms, but contributes over $60 \%$ of national pork production volume [7]. The distribution of SCFS mostly associated with the density of the human population and travel time to the provincial capital 
city [4]. Little information is available on factors affecting farmers' market power and income of contract pig farms [3]. However, there are limit data based on productive performance and operating income of SCFS in this region. The objective of this study aimed to evaluate the productive performance of SCFS in Northern Thailand and built multiple regression models to predict expected operating income as a monitoring tool to enhance the management efficiency of farms.

\section{Materials and Methods}

Between March 2014 and March 2017, 10 of 94 SCFS in Lampang province $\left(18^{\circ} 17^{\prime} 32.35^{\prime \prime} \mathrm{N}\right.$, 99²9'33.97" E) Northern Thailand were selected by purposive sampling to evaluate productive performance and operating income. The questionnaire and interview were used as tools to access primary data while the secondary data were obtained from individual farm records for two consecutive fattening cycles. Data on productive performance were analyzed using descriptive statistics [8]. Operating income is calculated as operating income $=$ gross income - operating expense [9]. Then, multiple linear regression models were built to estimate the predicted operating income (POI). Independent variables included herd size or number of animal per farm (HS, head), culling rate (CR, \%), mortality rate (MR, \%), average body weight (ABW, $\mathrm{kg}$ ), feed intake (FI, $\mathrm{kg} / \mathrm{d}$ ), average daily gain (ADG, $\mathrm{g} / \mathrm{d}$ ), feed conversion ratio (FCR) and fattening time (FT, d). Therefore, the statistical model was as the following equation:

$$
\mathrm{POI}_{i j}=\beta_{0}+\beta_{1} \mathrm{HS}_{i j}+\beta_{2} \mathrm{CR}_{i j}+\beta_{3} \mathrm{MR}_{i j}+\beta_{4} \mathrm{ABW}_{i j}+
$$

$\beta_{5} \mathrm{FI}+\beta_{6} \mathrm{ADG}_{i j}+\beta_{7} \mathrm{FCR}_{i j}+\beta_{8} \mathrm{FT}_{i j}+\varepsilon_{i j}$ where $i=1,2, \ldots \ldots 10$ (farm); $j=1,2$ (rearing cycles); POI was calculated in Thai baht (THB) $(1 \mathrm{THB}=$ 0.032 United States Dollar, USD); $\beta_{0}, \beta_{1}, \ldots \ldots \beta_{8}=$ regression coefficients; $\varepsilon_{i j}=$ model error.

Tests on a subset of multiple regression parameters and individual regression coefficients were performed using a two-tailed $t$-test as described by Myers [10]. Prediction model variables were selected using forward stepwise selection. Collinearity was determined in each model by calculating the variance inflation factor (VIF) for each retained variable. If VIF was greater than 10, collinearity was suspected. Then, variables were removed and predicted models were rebuilt until the VIF for all variables was less than $10[8]$.

\section{Results and Discussion}

The productive performance of swine under the management of SCFS is shown in Table 1. The characteristic of SCFS was mainly the feeder pig finishing system in which mixed piglets (gilt and barrow) were raised until market weight. The breed of swine was three or four crossbred line mainly from Large White, Landrace and Duroc which intended to produce high marbling in red meat due to the effect of hybrid vigor [11]. The HS ranged from 299 head/farm

Table 1 Productive performance of small-scale contract farming of swine (SCFS).

\begin{tabular}{lllll}
\hline Items & Mean & SD & Min & Max \\
\hline Number of animal, head/farm & 502 & 151.84 & 299 & 769 \\
Initial weight, $\mathrm{kg}$ & 6.12 & 0.59 & 5.11 & 7.24 \\
Final weight, $\mathrm{kg}$ & 110.45 & 4.17 & 104.35 & 117.37 \\
FI, kg/h/d & 1.59 & 0.10 & 1.24 & 1.72 \\
ADG, g/d & 675.22 & 22.01 & 623 & 706.30 \\
FCR & 2.42 & 0.17 & 1.81 & 2.60 \\
CR, \% & 0.17 & 0.30 & 0 & 1.08 \\
MR, \% & 2.50 & 1.29 & 0.57 & 5.38 \\
FT, d & 158.10 & 7.72 & 146 & 172 \\
\hline FI
\end{tabular}

FI = feed intake; $\mathrm{ADG}=$ average daily gain; $\mathrm{FCR}=$ feed conversion ratio; $\mathrm{CR}=$ culling rate; $\mathrm{MR}=$ mortality rate; $\mathrm{FT}=$ fattening time. 
to $769 \mathrm{head} /$ farm. The ratio of HS between less than $500 \mathrm{head} /$ farm and more than 500 head/farm was $52.63: 47.36$ compared to $18.75: 81.25$ of SCFS in a province of Southern Thailand [12]. Weaned piglets including gilt and barrow were provided by contract companies at averaged $6.12 \mathrm{~kg}$ of body weight for SCFS to raise until reaching their slaughter weight at $110.45 \mathrm{~kg}$ of body weight. The average date of the FT was $158 \mathrm{~d}$. FCR ranged from 1.81 to 2.60 or averaged 2.42 and was very effective compared to those previous studies $[13,14]$. The feeding system of all SCFS was an automatic pig feeder with unrestricted access to water. The CR and MR were relatively low, which reflected healthy herd and excellent health management due to the heard health care program and biosecurity system. In general benchmarks, FCR should be less than 3.2 and the MR should be less than $3 \%$ [15]. Most of Lampang SCFS or $78.94 \%$ established a biosecurity system to prevent the outbreak of disease. In addition, $47.36 \%$ of SCFS set a biogas system to produce gas from manure to reduce electricity cost with environmental friendly. All SCFS housings were designed as closed housing with a cooling evaporation system to prevent disease as well as environmental control.

Operating income is a tool to measure the amount of payment that the contract company paybacks to pig farm owners after deducting all operating expenses such as feed supply and veterinary service. To understand the ability of SCFS operation, operating income should be closely followed by farm owners and compare to those other SCFSs to gain monitoring for farm success.

In this study, HS, CR, MR, ABW, FI, ADG, FCR and FT were used as independent parameters to build multiple linear regression model to predict operating income as dependent parameter. A summary of the predicted model for operating income/animal including all variables in the model is shown in Table 2. Within this model, all coefficients did not show any significant difference $(p>0.05)$. With $r^{2}=0.808$, this implied that the eight-variable regression model explained $80.80 \%$ of the variation in POI [10]. However, the $F$-statistics $(F=5.255)$ was statistically significant $(p=0.009)$, indicating that at least one of the independent variables had the capability of influencing POI and this model required the process of variable selection to achieve the appropriate predicted model. In this study, the stepwise procedure was selected to fit the best prediction model in which all independent variables in the model were evaluated through the partial $F$-test. At each stage, a variable can be entered, and another may be eliminated. Thus, at all stages, a variable must continue to perform or be eliminated [10].

A summary of the variables retained in the predicted model after the stepwise procedure is shown in Table 3. The variables that were retained in the

Table 2 Estimation of predicted operating income as dependent variable included all variables.

\begin{tabular}{lllll}
\hline Variable & Coefficient & SE & $t$-statistic & $p$-value \\
\hline Intercept & $2,700.912$ & $1,671.797$ & 1.616 & 0.137 \\
HS & 0.027 & 0.060 & 0.460 & 0.655 \\
CR & -7.119 & 23.544 & -0.302 & 0.769 \\
MR & -18.225 & 8.524 & -2.138 & 0.058 \\
ABW & 16.885 & 11.104 & 1.521 & 0.159 \\
FI & 806.466 & 840.955 & 0.959 & 0.360 \\
ADG & -4.142 & 2.342 & -1.769 & 0.107 \\
FCR & -420.281 & 563.536 & -0.746 & 0.473 \\
FT & -9.719 & 6.951 & -1.398 & 0.192 \\
\hline
\end{tabular}

$F$-statistics $=5.255, p$-value $=0.009, r=0.899, r^{2}=0.808$, Durbin-Watson $=1.446$

$\mathrm{HS}=$ herd size; $\mathrm{CR}=$ culling rate; $\mathrm{MR}=$ mortality rate; $\mathrm{ABW}=$ average body weight; $\mathrm{FI}$ = feed intake; $\mathrm{ADG}=$ average daily gain; $\mathrm{FCR}=$ feed conversion ratio; $\mathrm{FT}=$ fattening time. 

Farming of Swine in Lampang, Thailand

Table 3 Estimation of predicted operating income with model selection by stepwise method.

\begin{tabular}{|c|c|c|c|c|c|}
\hline Model & Variable & Coefficient & SE & $t$-statistic & $p$-value \\
\hline \multirow[t]{2}{*}{1} & Intercept & -63.299 & 102.486 & -6.18 & 0.545 \\
\hline & FI & 333.819 & 64.122 & 5.206 & 0.000 \\
\hline \multicolumn{6}{|c|}{$F$-statistics $=27.102, p$-value $=0.000, r=0.784, r^{2}=0.615$, Durbin-Watson $=2.012$} \\
\hline \multirow[t]{3}{*}{2} & Intercept & -22.635 & 95.021 & -0.238 & 0.815 \\
\hline & FI & 323.664 & 58.448 & 5.538 & 0.000 \\
\hline & MR & -9.769 & 4.557 & -2.144 & 0.048 \\
\hline
\end{tabular}

F-statistics $=18.716, p$-value $=0.000, r=0.837, r^{2}=0.701$, Durbin-Watson $=2.012$

$\overline{\mathrm{FI}}=$ feed intake; $\mathrm{MR}=$ mortality rate.

predictive model were separated into two models including: $\mathrm{POI}=333.819 \mathrm{FI}-63.299$ with $F=27.102$, $p$-value $=0.000, r=0.784, r^{2}=0.615($ Model 1$)$ and $\mathrm{POI}=323.664 \mathrm{FI}-9.769 \mathrm{MR}-22.635$ with $F=$ $18.716, p$-value $=0.000, r=0.837, r^{2}=0.70$ (Model $2)$. In the first model, the FI variable could explain $61.50 \%$ of the variation in operating income while both FI and MR in the second model could explain $70 \%$ of the variation in the operating income which reflected a positive dependence of regression equation and more reliability to predict operating income. According to this study, the operating income of Lampang SCFS was $469.23 \mathrm{THB} /$ pig, 8.63\% lower than those of SCFS in Southern Thailand that received $513.59 \mathrm{THB} /$ pig [12].

\section{Conclusions}

The productive performance of SCFS in Lampang, Thailand clearly illustrated farm efficiency due to high ADG, low in FCR, CR as well as MR. FI and MR were shown to be potential variables for operating income prediction.

\section{References}

[1] DLD. 2018. Statistics of Livestock Farmers in Thailand. Department of Livestock Development, Ministry of Agriculture and Cooperatives. Accessed July 18, 2018. http://ict.dld.go.th/webnew/index.php/th/service-ict/report /247-report-thailand-livestock.

[2] Tantasuparuk, W., and Kunavongkrit, A. 2015. Pig Production in Thailand. Country Report. Accessed May 30, 2019. https://www.angrin.tlri.gov.tw/English/2014S wine/p136-144.pdf.

[3] Tiongco, M., Catelo, M. A., and Lapar, M. L. 2008. "Contract Farming of Swine in Southeast Asia as a
Response to Changing Market Demand for Quality and Safety in Pork." International Food Policy Research Institute, Washington, DC.

[4] Thanapongtharm, W., Linard, C., Chinson, P., Kasemsuwan, S., Visser, M., Gaughan, A. E., Epprech, M., Robinson, T. P., and Gilbert, M. 2016. "Spatial Analysis and Characteristics of Pig Farming in Thailand." BMC Veterinary Research 12: 218.

[5] Singh, S. 2005. "Contract Farming System in Thailand." Economic and Political Weekly 40 (53): 5578-86.

[6] Bunprasert, J., Khlibtong, J., and Tangwiwat, P. 2012. "Hog Raising by Farmers Participating in the Hog Fattening Employment Project under Betragro Ago Industry Co., Ltd at Phitsanulok Office.” In Proceedings of the 2nd STOU Graduate Research Conference, Sukhothai Thammathirat Open University, 1-10. (in Thai)

[7] Office of Agriculture Economics. 2017. Report of Important Agricultural Goods and Trend in 2018. Ministry of Agriculture and Cooperatives, Thailand. Accessed May 30, 2019. http://www.oae.go.th.

[8] SPSS. 2006. Statistical Package for the Social Sciences. Version 15th ed. for Windows, Chicago, IL.

[9] Damodaran, A. 1999. "Dealing with Operating Leases in Valuation." New York University Stern School of Business. Accessed May 30, 2019. https://archive.nyu.edu/bitstream/2451/26922/2/wpa9902 3.pdf.

[10] Myers, R. H. 1990. Classical and Modern Regression with Application, 2nd ed. Belmont, California: PWS-KENT Publishing Company.

[11] Tang, Z., Peng, Z., Liu, B., Fan, B., Zhao, S., Li, X., Xu, S., and Li, K. 2008. "Effect of Breed, Sex and Birth Parity on Growth, Carcass and Meat Quality in Pigs." Front. Agric. China 2 (3): 331-7.

[12] Maneemai, P., Jarernkitjarukorn, P., Kemawanit, T., Manojai, C., and Isarakumkerng, G. 2015. "Costs and Returns of Small and Medium Scale Fattening Swine Production: A Case Study of Individual and Contract Farming in Phatthalung Province." Modern Management J. 13 (1): 93-105. (in Thai)

[13] Mutua, F. K., Dewey, C. E., Arimi, S. M., Schelling, E., 

Farming of Swine in Lampang, Thailand

and Ogara, W. O. 2011. "Prediction of Live Body Weight Using Length and Girth Measurements for Pigs in Rural Western Kenya." J. Swine Health Prod. 19 (1): 26-33.

[14] Ball, M. E. E., Magowan, E., McCracken, K. J., Beattie, V. E., Bradford, R., Gordon, F. J., Robinson, M. J., Smyth, S., and Henry, W. 2013. "The Effect of Level of
Crude Protein and Available Lysine on Finishing Pig Performance, Nitrogen Balance and Nutrient Digestibility." Asian-Australas J. Anim. Sci. 26 (4): 564-72.

[15] Taylor, R. E., and Field, T. G. 2001. Scientific Farm Animal Production, 7th ed. New Jersey: Prentice Hall. 